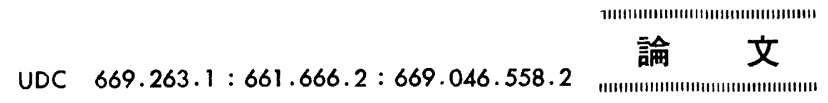

\title{
各種合成クロマイトの炭素還元挙動
}

$$
\text { 片山博**. 徳 田昌 則*** }
$$

\section{The Reduction Behavior of Synthetic Chromites by Carbon}

\author{
Hiroshi G. Katayama and Masanori Tokuda
}

Synopsis:

The chromites shown below were prepared synthetically and reduced by graphite powder under a $\mathrm{CO}$ atmosphere: $\mathrm{FeCr}_{2} \mathrm{O}_{4}(\mathrm{Sp} 1), \mathrm{MgCr}_{2} \mathrm{O}_{4}(\mathrm{Sp} 2)$, $\left(\mathrm{Fe}_{\mathbf{0 . 5}} \mathrm{Mg}_{\mathbf{0 . 5}}\right) \mathrm{Cr}_{2} \mathrm{O}_{4}(\mathrm{Sp} 3),\left(\mathrm{Fe}_{\mathbf{0 . 5}} \mathrm{Mg}_{\mathbf{0} .5}\right)\left(\mathrm{Cr}_{\mathbf{0} .8} \mathrm{Al}_{\mathbf{0 . 2}}\right)_{2} \mathrm{O}_{\mathbf{4}}(\mathrm{Sp} 4)$, and $\mathrm{Mg}\left(\mathrm{Cr}_{0.6} \mathrm{Al}_{0.4}\right)_{2} \mathrm{O}_{4}(\mathrm{Sp} 5)$.

The results obtained are as follows:

1) In the case of the pure iron chromite $\mathrm{Sp} 1$, the reduction of $\mathrm{FeO}$ component preceded that of $\mathrm{Cr}_{2} \mathrm{O}_{3}$. With the progress of the reduction, the metallic products changed in the following order: Austenite $\rightarrow$ austenite $+(\mathrm{Fe}, \mathrm{Cr}){ }_{3} \mathrm{C} \rightarrow(\mathrm{Fe}, \mathrm{Cr})_{3} \mathrm{C}+(\mathrm{Gr}, \mathrm{Fe})_{7} \mathrm{C}_{3} \rightarrow(\mathrm{Gr}, \mathrm{Fe})_{7} \mathrm{C}_{3}$.

2) The reduction of complex chromites containing iron oxide ( $\mathrm{Sp} 3$ and $\mathrm{Sp} 4$ ) took place in two stages. In the first stage with the reduction of the $\mathrm{FeCr}_{2} \mathrm{O}_{4}$ component, $\mathrm{FeO}$ and $\mathrm{Cr}_{2} \mathrm{O}_{3}$ were reduced simultaneously at temperatures higher than $1150^{\circ} \mathrm{C}$, although the reduction of $\mathrm{FeO}$ preceded at lower temperatures. The reduction of the $\mathrm{MgCr}_{2} \mathrm{O}_{4}$ component (the second stage) required higher temperatures. It started at $1200^{\circ} \mathrm{C}$ and proceeded rapidly at temperatures higher than $1250^{\circ} \mathrm{G}$ in the case of $\mathrm{Sp} 2$ and $\mathrm{Sp} 3$. The rapid progress of the reduction of $\mathrm{MgCr}_{2} \mathrm{O}_{4}$ component of $\mathrm{Sp} 4$ and $\mathrm{Sp} 5$ which contained $\mathrm{Al}_{2} \mathrm{O}_{3}$ was only encountered at temperatures higher than $1330^{\circ} \mathrm{C}$.

3) The metallic product of the chromites $\mathrm{Sp} 3$ and $\mathrm{Sp} 4$ was $(\mathrm{Cr}, \mathrm{Fe})_{7} \mathrm{C}_{3}$ in either reduction stage of the $\mathrm{FeCr}_{2} \mathrm{O}_{4}$ and $\mathrm{MgCr}_{2} \mathrm{O}_{4}$ components. The final product of the reduction of the chromites $\mathrm{Sp} 2$ and $\mathrm{Sp} 5$ was $\mathrm{Cr}_{3} \mathrm{C}_{2}$, while an unidentified phase appeared during the course of the reduction and was considered to be chromium oxycarbide.

\section{1. 緒言}

著者の 1 人はこれまでに各種銘柄のクロマイトについ て固相域に打ける炭素還元実験を行い，還元過程および 還元性におよぼすクロマイトの組成および脈石鉱物の影 響1)ならびに各種雲囲気中における炭素還元挙動2をを検 討してきた．しかし天然のクロマイトは $(\mathrm{Fe}, \mathrm{Mg})(\mathrm{Cr}$, $\mathrm{Al}, \mathrm{Fe}){ }_{2} \mathrm{O}_{4}$ なる一般式で表わされる組成の複䧱なスピ ネル固溶体であるためその還元挙動も複雑となり，した がって十分解明できない問題をいくつか残している。そ のためひき続いてクロマイトの基本成分である $\mathrm{Cr}_{2} \mathrm{O}_{3}{ }^{3}$ ， $\mathrm{FeCr}_{2} \mathrm{O}_{4}{ }^{4)}$ および $\mathrm{MgCr}_{2} \mathrm{O}_{4}{ }^{5)}$ の $\mathrm{Ar}$ 雾囲気中に拈ける 炭素還元実験を行い基礎的知識を得てきた。

本報においては上記の $\mathrm{FeCr}_{2} \mathrm{O}_{4}$ および $\mathrm{MgCr}_{2} \mathrm{O}_{4}$ の ほかにさらに $\left(\mathrm{Fe}_{0.5} \mathrm{Mg}_{0.5}\right) \mathrm{Cr}_{2} \mathrm{O}_{4},\left(\mathrm{Fe}_{0.5} \mathrm{Mg}_{0.5}\right)\left(\mathrm{Cr}_{0.8}\right.$ $\left.\mathrm{Al}_{0.2}\right)_{2} \mathrm{O}_{4}, \mathrm{Mg}\left(\mathrm{Cr}_{0.6} \quad \mathrm{Al}_{0.4}\right)_{2} \mathrm{O}_{4}$ などの複クロマイトを
合成し, $\mathrm{CO}$ 雾囲気中における炭素還元実験を行つてそ れぞれの還元過程を明らかにした. ついでこれらの結果 の比較からクロマイトの還元過程および還元性に及ぼす 組成の影響を検討し，あわせてクロム鉣石中のクロマイ トの炭素邀元挙動についても考察した。

\section{2. 試料および実験方法}

\section{$2 \cdot 1$ 試 料}

クロマイトの合成に用いた原料酸化物は市販の特級試 薬の $\mathrm{MgO}, \mathrm{Cr}_{2} \mathrm{O}_{3}, \mathrm{Fe}_{2} \mathrm{O}_{3}$ および $\mathrm{Al}_{2} \mathrm{O}_{3}$ である. $\mathrm{MgO}$ はあらかじめ $900^{\circ} \mathrm{C} に 1 \mathrm{~h}$ 加熱し，また他の酸 化物は $120^{\circ} \mathrm{C}$ にて $5 \mathrm{~h}$ 乾燥し揮発分および水分を除去 した。これらの酸化物から次のような方法により Table 1 に示す 5 種のクロマイトを合成した.

$\mathrm{Sp} 1$ は $\mathrm{Cr}_{2} \mathrm{O}_{3}$ と $\mathrm{Fe}_{2} \mathrm{O}_{3}$ のモル比 $2: 1$ の混合物を

* 昭和 50 年 10 月本会謱演大会にて一部発表 昭和 53 年 5 月 11 日受付 (Received May 11, 1978)

** 室蔽工業大学金属工学科 (Dept. of Metallurgy, Muroran Institute of Technology, 27-1 Mizumoto-cho Muroran 050)

*** 東北大学選鉱弊鍊研究所 工博 (Research Institute of Mineral Dressing and Metallurgy, Tohoku University) 
Table 1. Densities and lattice parameters of synthetic chromites.

\begin{tabular}{|c|c|c|c|c|c|}
\hline & \multirow{2}{*}{ Chromite } & \multicolumn{2}{|c|}{ Density $\left(\mathrm{g} / \mathrm{cm}^{3}\right)$} & \multicolumn{2}{|c|}{ Lattice parameter $(\AA)$} \\
\hline & & This work & Ref & This work & Ref \\
\hline Sp 1 & $\mathrm{FeCr}_{2} \mathrm{O}_{4}$ & 4.91 & $\begin{array}{l}5.09^{7)} \\
5.08^{8)}\end{array}$ & 8.35 & $\begin{array}{l}8.36^{6)} \\
8.35^{7)} \\
8.34^{8)}\end{array}$ \\
\hline Sp 2 & $\mathrm{MgCr}_{2} \mathrm{O}_{4}$ & 4.45 & $\begin{array}{l}4.43^{7)} \\
4.42^{8)} \\
4.41^{9)}\end{array}$ & 8.32 & $\begin{array}{l}8.32^{6) 7)} \\
8.31^{8)} \\
8.33^{91}\end{array}$ \\
\hline Sp 3 & $\left(\mathrm{Fe}_{0.5} \mathrm{Mg}_{0.5}\right) \mathrm{Cr}_{2} \mathrm{O}_{4}$ & 4.66 & $4.75^{*}$ & 8.34 & $8.33 *$ \\
\hline Sp 4 & $\left(\mathrm{Fe}_{0.5} \mathrm{Mg}_{0.5}\right)\left(\mathrm{Cr}_{0.8} \mathrm{Al}_{0.2}\right)_{2} \mathrm{O}_{4}$ & 4.54 & $4.57 *$ & 8.30 & $8.28 *$ \\
\hline Sp 5 & $\mathrm{Mg}\left(\mathrm{Cr}_{0.6} \mathrm{Al}_{0.4}\right)_{2} \mathrm{O}_{4}$ & 4.13 & $4.07 *$ & 8.23 & $8.22 *$ \\
\hline
\end{tabular}

* Calculated according to Vegard's law using values in the literature ${ }^{8)}$.

製団* 後, まず空気中 $1250^{\circ} \mathrm{C}$ にて $3 \mathrm{~h}$, さらに粉挽, 製団を行つたのち $24 \mathrm{~h}$ 加熱して固溶体 $(\mathrm{Cr}, \mathrm{Fe})_{2} \mathrm{O}_{3}$ を作り，ついでこれを $1: 1 の \mathrm{H}_{2}-\mathrm{CO}_{2}$ 混合ガス気流中 $1300^{\circ} \mathrm{C}$ にて $10 \mathrm{~h}$ 還元して合成した. Sp 2 は $\mathrm{MgO}$ と $\mathrm{Cr}_{2} \mathrm{O}_{3}$ の等モル混合物を製団後空気中 $1300^{\circ} \mathrm{C}$ にて $5 \mathrm{~h}$, ついで粉砕，製団を行つたのち，さらにに $5 \mathrm{~h}$ 加熱して 得た. Sp 5 は $\mathrm{Sp} 2$ に所定量の $\mathrm{MgO}$ と $\mathrm{Al}_{2} \mathrm{O}_{3}$ を混 合し, $\mathrm{Sp} 2$ と同様の条件で合成したが，反応が括そい ために合計 $20 \mathrm{~h}$ 加熱した. Sp 3 は Sp 1 と Sp 2 の等 モル混合物を製団後 $1: 1$ の $\mathrm{CO}-\mathrm{CO}_{2}$ 混合ガス気流中 $1300^{\circ} \mathrm{C}$ にて $5 \mathrm{~h}$, ついで粉砕, 製団したのちさらに $5 \mathrm{~h}$ 加熱して得た。 また Sp 4 は Sp 1 と Sp 5 の等モル 混合物から Sp 3 と同様に合成した。 これらの生成物は 擂潰機で 250 ×ッン以下に粉砕し，還元実験に供し た.なお Sp 1 にかぎつては325 メッシュ以下をふるい 落したが，目詰りか激しく若干の微粉分が混入している と思われる。

以上のようにして得たクロマイトはいずれも単一相で あることをX線回折により確認した，密度および格子定 数の測定結果を Table 1 に示す。な㨸度は浸液とし てメチルアルコールを用いピクノメータ法により测定し た. 格子定数は $\mathrm{Cu} \cdot \mathrm{K} \alpha$ 線により得られた (440) 面の回 折ピークの角度から求めたが, そのさいの標準物質とし ては特級試薬の $\mathrm{NaCl}$ を用いた。

Table 1 には従来報告されている $\mathrm{FeCr}_{2} \mathrm{O}_{4}$ と $\mathrm{MgCr}_{2} \mathrm{O}_{4}$ の密度扣よび格子定数の値6) -9) も示してある.これらと 比較して本実験の Sp 1 および Sp 2 は格子定数がよく 一致し，また密度にも大差がない。 $\mathrm{Sp} 3, \operatorname{Sp} 4$ および Sp 5 の場合は各成分スピネルの従来の報告值8)を用い Vegard の法則にしたがつて求めた值を示したが丰測值

* 製団は試料約 $10 \mathrm{~g}$ 支直径 $17 \mathrm{~mm}$ の金型に入れ, $2000 \mathrm{~kg} / \mathrm{cm}^{2}$ の 王力で行つた。
Table 2. The ratios of graphite to chromite, initial carbon contents, and weight losses corresponding to complete reduction.

\begin{tabular}{c|c|c|c|c}
\hline $\begin{array}{c}\text { Chro- } \\
\text { mite }\end{array}$ & \multicolumn{2}{|c|}{$\begin{array}{l}\text { Mole ratio of car- } \\
\text { bon to chromite }\end{array}$} & $\begin{array}{c}\text { Carbon } \\
\text { content } \\
\text { (wt \%) }\end{array}$ & $A$ (wt \%) \\
\cline { 2 - 5 } & Actual & Equivalent* & \\
\hline Sp 1 & 5.5 & 5.28 & 22.79 & 38.65 \\
Sp 2 & 4.5 & 4.33 & 21.94 & 34.11 \\
Sp 3 & 5.0 & 4.57 & 22.40 & 36.56 \\
Sp 4 & 4.5 & 3.80 & 21.44 & 32.22 \\
Sp 5 & 3.5 & 2.60 & 19.61 & 23.52 \\
\hline
\end{tabular}

$A$ : Weight loss corresponding to complete reduction*.

* Final products are assumed to be $(\mathrm{Cr}, \mathrm{Fe})_{7} \mathrm{C}_{3}$ for $\mathrm{Sp} 1, \mathrm{Sp} 3$ and $\mathrm{Sp} 4$ and $\mathrm{Cr}_{3} \mathrm{C}_{2}$ for $\mathrm{Sp} 2$ and $\mathrm{Sp} 5$. Gaseous product is assumed to be $\mathrm{CO}$ only.

はこれらに比較的近似している.

還元剂は前報4) 5 ) と同様に 黒鉛電極棒を粉研し，250 〜325メッシュにふるい分けたものであり，あらかじめ $\mathrm{N}_{2}$ 雾囲気中 $900^{\circ} \mathrm{C}$ に約 $1 \mathrm{~h}$ 加熱し水分などを除去し た.なお，その灰分は $0.10 \%$ 以下であつた。

クロマイトに対する黒鉛粉末の配合量は Table 2 に まとめて示した．配合モル比はクロマイトにより相違す るが，混合物中の炭素量は比較的近似している. 同表に 示した当量配合モル比は既報45) の結果から，鉄を含む クロマイトの場合は $(\mathrm{Cr}, \mathrm{Fe})_{7} \mathrm{C}_{3}$, 鉄を含なない場合は $\mathrm{Cr}_{3} \mathrm{C}_{2}$ が各々還元により生成し，かつ生成ガスは $\mathrm{CO}$ のみであるとして求めた值である．これと比较して実際 の配合比はいずれも過剩である、Aは $100 \%$ 還元に相当 寸る混合物の重量減少率であり, 被還元成分は $\mathrm{FeO}$ と $\mathrm{Cr}_{2} \mathrm{O}_{3}$ で生成ガスは $\mathrm{CO}$ のみであるとして算出した。

クロマイトと黒鉛粉末は入念に混合したのちその $0.5 \mathrm{~g}$ を内径 $9 \mathrm{~mm}$, 深さ $9 \mathrm{~mm}$ の黒鉛るつぼに充てんし還 元実験に供した. ただし Sp 2 は比較的微粒のためか さばつて黒鉛るつぼへの充てんが困難であつたので, 


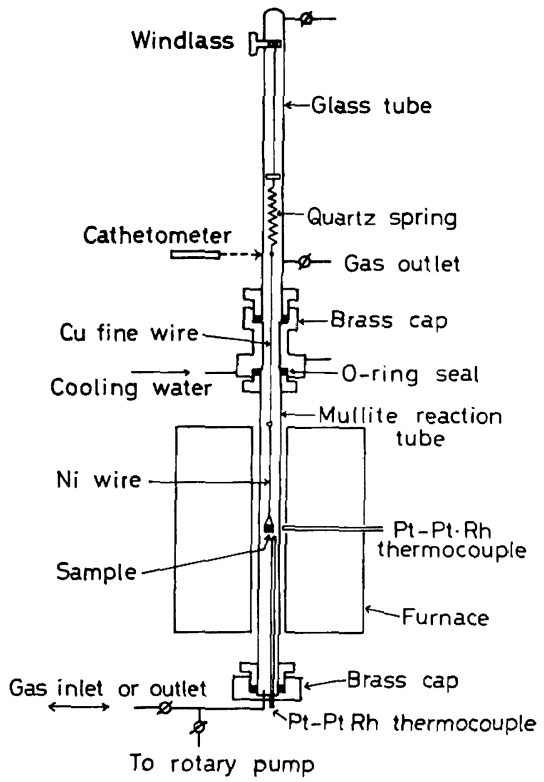

Fig. 1. Experimental apparatus.

$\mathrm{Cr}_{2} \mathrm{O}_{3}$ の場合と同椂の方法3) により造粒し直径約 $8 \mathrm{~mm}$ のペレットとして用いた。

\section{$2 \cdot 2$ 実験方法}

還元装置はFig. 1 に示すよらに石英スプリングを用 いた熱天科で，反応管の内径は $28 \mathrm{~mm}$ である、炉温は 自動温度調節計により $\pm 3^{\circ} \mathrm{C}$ に保持した。反応管内の均 熱部 $\left( \pm 1^{\circ} \mathrm{C}\right)$ は約 $40 \mathrm{~mm}$ であり，この範囲内に熱電 対の先端および試料が位置するようにした。

還元操作の概要は次のよらである. 混合物試料を充て んした黒鉛るつぼまたはぺレット試料は $0.4 \mathrm{~mm} \phi$ の $\mathrm{Ni}$ 線で作製したバスケットにのせ，反応管の上端につ り下げ，ガラス管を気密に連結した，反応管内を $10^{-2}$ $\mathrm{mmHg}$ 程度をで排気したのち，後述の方法により精製 した CO ガスを導入した，ついでガラス管上端のウイ ンドラスをまわして試料を下げ，800〜 $900^{\circ} \mathrm{C}$ の位置で $3 \mathrm{~min}$, さらに最高温部に下げてから $2 \mathrm{~min}$ 予熱後力七 トメーターにより石英スプリングの変位の読みとりを開 始した. 所定時間経過後試料を反応管の上端に速やかに まき上げ，十分冷却後とり出して科量した。な打予熱期 間中の重量隇は同一条件で別に測定した。

$\mathrm{CO}$ ガスには市販のボンベガス (99.8\%以上)を用 い, これを $50 \%$ 水酸化カリウム溶液, アルカリ性亜二 チオン酸ナトリウム溶液, 塩化カルシウムおよび五酸化 リンの各洗浄系を通して精製し反応管に導入した。こ の CO ガスは反応管内を $\mathrm{CO}$ 雾囲気にするためにのみ 用い，還元時にはコックを切換え反応管内には流さなか
つた。な打還元によつて生成する主として CO から成 るガスは反応管の下部の導管から自然に流れ出る状態と し，反応系の圧力を 1 気圧に保つた.

還元率 $(R)$ 法次式により算出した.

$$
R=\left\{\frac{\left(L_{t}-L_{p}\right)\left(W_{p}-W_{e}\right)}{L_{e}-L_{p}}+\left(W_{o}-W_{p}\right)\right\} \frac{100}{W_{o} A}
$$

ここで $W_{o}, W_{p}, W_{e}$ は混合物試料の還元前，予熱後拈 よび還元後の重量， $L_{p} ， L_{t}, L_{e}$ は水平顕微鏡の測定開 始時, $\mathrm{t}$ 時間後および測定終了時の読みである. Aの值 としては生成ガスが CO のみであるとみなせるので1， Table 2 に示した値をそのまま用いた.

還元試料については $\mathrm{Cu} \cdot \mathrm{K}_{\alpha}$ 線を用いた粉末法によ るX線回折を行い生成物を固定した。

\section{3. 実 験 結 果}

\section{$3 \cdot 1$ クロマイト $\left(\mathrm{FeCr}_{2} \mathrm{O}_{4}\right)$}

このクロマイトについて 1 090〜1 $180^{\circ} \mathrm{C}$ 間の各温度 にて還元速度を測定した結果を Fig. 2 に示す。図中の 破線はクロマイト中の $\mathrm{FeO}$ 成分のみが $100 \%$ 還元した ときの還元率 $\left(R_{F}=25 \%\right)$ に相当するが，この還元率 をこ兊ると $1150^{\circ} \mathrm{C}$ 以下の温度では還元速度が急激に 低下する．このことから $\mathrm{FeCr}_{2} \mathrm{O}_{4}$ は初め $\mathrm{FeO}$ 成分が 還元し，その後遊離した $\mathrm{Cr}_{2} \mathrm{O}_{3}$ の還元が起こることが 容易に推定できる.

この過程をさらに詳細に調査するために種々の還元段 階の試料についてX線回折を行い, 得られた回折図の数 例を Fig 3 に示した，還元率が $R_{F}$ より低い試料では 未還元の $\mathrm{FeCr}_{2} \mathrm{O}_{4}, \mathrm{FeO}$ 成分の優先還元により遊離し た $\mathrm{Cr}_{2} \mathrm{O}_{3}$ と共に還元生成物としては $\alpha-\mathrm{Fe}$ (還元温度 では $\gamma$ 固溶体) および $(\mathrm{Fe}, \mathrm{Cr}){ }_{3} \mathrm{C}^{*}$ が同定された，逗

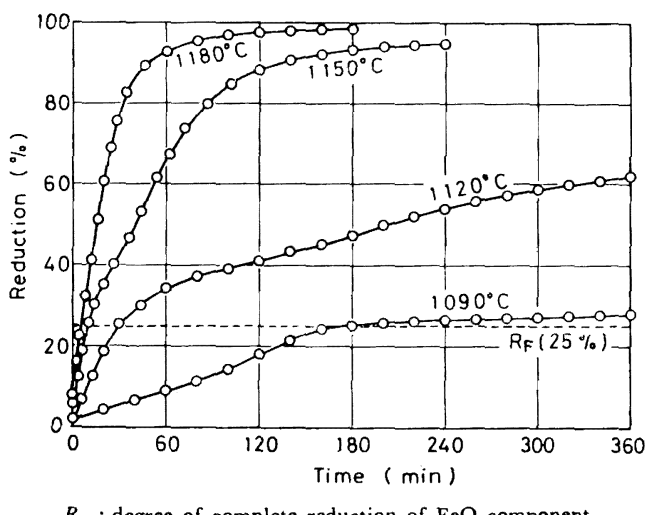

$R_{F}$ : degree of complete reduction of $\mathrm{FeO}$ component

Fig. 2. Reduction curves of $\mathrm{FeCr}_{2} \mathrm{O}_{4}$ at various temperatures.

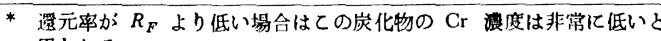
思われる. 


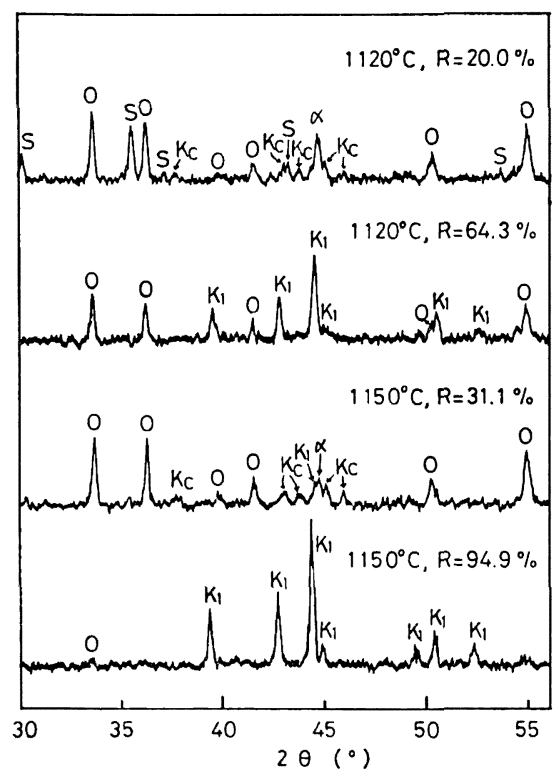

$S: \mathrm{FeCr}_{2} \mathrm{O}_{4}, O: \mathrm{Cr}_{2} \mathrm{O}_{3}, \alpha: \alpha-\mathrm{Fe}, K_{C}:(\mathrm{Fe}, \mathrm{Cr}){ }_{3} \mathrm{C}$, $K_{1}:(\mathrm{Cr}, \mathrm{Fe}){ }_{7} \mathrm{C}_{3}$

Fig. 3. X-ray diffraction patterns of $\mathrm{FeCr}_{2} \mathrm{O}_{4}$ reduced at 1120 and $1150^{\circ} \mathrm{C}$.

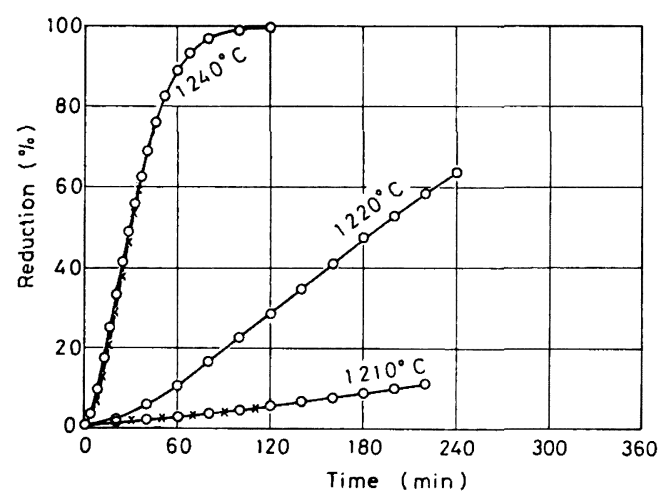

Fig. 4. Reduction curves of $\mathrm{MgCr}_{2} \mathrm{O}_{4}$ at various temperatures.

元率が $R_{F}$ をこえると $\mathrm{FeCr}_{2} \mathrm{O}_{4}$ は消失し酸化物相は $\mathrm{Cr}_{2} \mathrm{O}_{3}$ のみとなる. 還元生成物は還元率が $30 \%$ 程度ま では主として $\alpha-\mathrm{Fe}$ おひひ $(\mathrm{Fe}, \mathrm{Cr})_{3} \mathrm{C}$ であるが，さ らに還元率が高くなるとこれらは消失し, $(\mathrm{Cr}, \mathrm{Fe}){ }_{7} \mathrm{C}_{3}$ の みが生成する。な抗この複炭化物の回折ピークは還元率 の上昇とともに次第に低角度側に移動し, 炭化物中の $\mathrm{Cr}$ 濃度の上昇に対応した変化を示した.

\section{2 ピクロクロマイト $\left(\mathrm{MgCr}_{2} \mathrm{O}_{4}\right)$}

このクロマイトの $1210 \sim 1240^{\circ} \mathrm{C}$ 間の温度に拈け る還元速度曲線を Fig. 4 と示す, 因中 1210 および

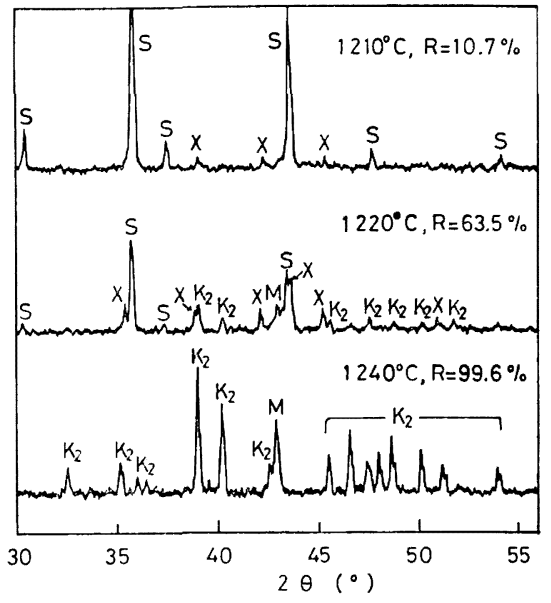

$S: \mathrm{MgCr}_{2} \mathrm{O}_{4}, M: \mathrm{MgO}, K_{2}: \mathrm{Cr}_{j} \mathrm{C}_{2}$

Fig. 5. X-ray diffraction patterns of $\mathrm{MgCr}_{2} \mathrm{O}_{4}$ reduced at various temperatures.

$1240^{\circ} \mathrm{C}$ の曲線上の○と $\times$ 印は 2 回の測定結果に対応し ており，再現性が十分に良好であることを示す．図より 還元速度の温度依存性が著しく大きいことが注目され る.

還元試料のX線回折図を Fig. 5 に示す. $1240^{\circ} \mathrm{C}$ の還 元試料は還元率が $100 \%$ に近いためにすでに $\mathrm{MgCr}_{2} \mathrm{O}_{4}$ の回折ピークは消失し, 同定されたのは $\mathrm{MgO}$ と $\mathrm{Cr}_{3} \mathrm{C}_{4}$ のみである.これに対して1210および $1220^{\circ} \mathrm{C}$ の還元 試料には $\mathrm{MgCr}_{2} \mathrm{O}_{4}, \mathrm{MgO}$ および $\mathrm{Cr}_{3} \mathrm{C}_{2}$ のほかに未知 の物質（以下X相といら）が検出され，また $1240^{\circ} \mathrm{C} に$ おいても還元率が低い試料は同様の回折像を示した。

\section{$3.3\left(\mathrm{Fe}_{0.5} \mathrm{Mg}_{0.8}\right) \mathrm{Cr}_{2} \mathrm{O}_{4}$}

$1090 \sim 1240^{\circ} \mathrm{C}$ 間の各温度で還元速度を測定した結果 を Fig. 6 に示す.な打図中の $R_{F}, R_{F C}, R_{M C}$ はそれぞれ $\mathrm{FeO}, \mathrm{FeCr}_{2} \mathrm{O}_{4}$ 扰よひ $\mathrm{MgCr}_{2} \mathrm{O}_{4}$ 成分を各々完全に還元 した重量変化に対応する還元率を表わす。図示されるよ らに Sp 1 とは異なり $R_{F}$ の近傍においては還元速度は とくに変化しない，しかし $R_{F C}$ をこえると還元速度は 急に低下し，たとえば $1150^{\circ} \mathrm{C}$ の場合還元率は約 60

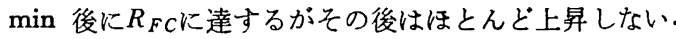
$R_{F C}$ より先の還元反応はさらに高温を必要とし， 1240 ${ }^{\circ} \mathrm{C}$ に打ける長時間還元によりようやく完了する.

次にいくつかの還元試料についてX線回折を行い, そ の結果の代表例を Fig. 7 に示した. $\mathrm{Cr}_{2} \mathrm{O}_{3}$ は 1120 お よび $1150^{\circ} \mathrm{C}$ の還元試料に少量ながら同定されたが, $1180^{\circ} \mathrm{C}$ 以上の温度ではまつたく認められなかつた。還 元生成物は常に $(\mathrm{Cr}, \mathrm{Fe})_{7} \mathrm{C}_{3}$ であつた. たた $1120^{\circ} \mathrm{C}$ 


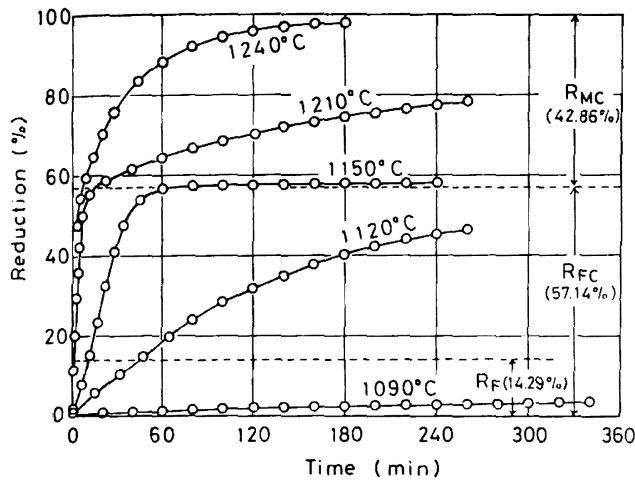

$R_{F}, R_{F C}, R_{H C}$ : degree of complete reduction of $\mathrm{FeO}, \mathrm{FeCr}_{2} \mathrm{O}_{4}$, and $\mathrm{MgCr}_{2} \mathrm{O}_{4}$ component, respectively.

Fig. 6. Reduction curves of $\left(\mathrm{Fe}_{0.5} \mathrm{Mg}_{0.5}\right) \mathrm{Cr}_{2} \mathrm{O}_{4}$ at various temperatures.

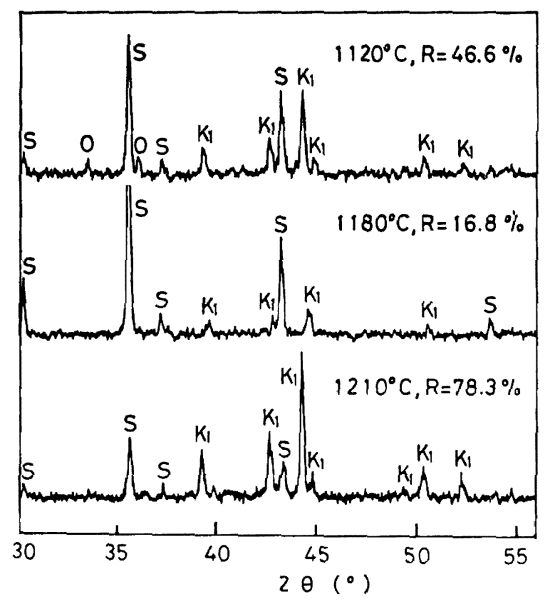

$S:$ chromite (initial composition : $\left(\mathrm{Fe}_{0.5} \mathrm{Mg}_{0.5}\right) \mathrm{Cr}_{2} \mathrm{O}_{4}$, ) $0: \mathrm{Cr}_{2} \mathrm{O}_{3}, K:(\mathrm{Cr}, \mathrm{Fe})_{7} \mathrm{C}_{3}$

Fig. 7. X-ray diffraction patterns of $\left(\mathrm{Fe}_{\mathbf{0 . 5}} \mathrm{Mg}_{\mathbf{0 . 5}}\right)$ $\mathrm{Cr}_{2} \mathrm{O}_{4}$ reduced at various temperatures.

の低還元率の試料には $(\mathrm{Fe}, \mathrm{Cr})_{3} \mathrm{C}$ と思われる微弱な回 折ピークも認如た。 クロマイトの回折ピークは還元 率か： $R_{F C}$ に達するまでは還元の進行にともない，わず かなから高角度側に移動したが， $R_{F C}$ をこえると一定と なり Sp 2 の回折ピークとはぼ一致した。還元率が高い 試料では $\mathrm{MgO}$ が同定された，ただし $\mathrm{MgO}$ の第 1 順 位の回折ピークは $(\mathrm{Cr}, \mathrm{Fe})_{7} \mathrm{C}_{3}$ の第 2 順位のそれと重複 するため第 2 順位の回折ピークにより同定したので, $\mathrm{MgO}$ の生成量が少ない場合は検出できなかつたるのと 思われる。

以上より $\mathrm{Sp} 3$ の炭素還元過程をまとめてみると，ま ず $\mathrm{FeCr}_{2} \mathrm{O}_{4}$ 成分が侵先還元し，その後避離した $\mathrm{Mg}$
$\mathrm{Cr}_{2} \mathrm{O}_{4}$ の還元が起こる.な扰 $\mathrm{FeCr}_{2} \mathrm{O}_{4}$ 成分の還元段階 に扮いて性, $\mathrm{FeO}$ と $\mathrm{Cr}_{2} \mathrm{O}_{3}$ の禹成分が同時に還元され る.ただし $1150^{\circ} \mathrm{C}$ 以下では $\mathrm{FeO}$ の還元がいく分速 く少量の $\mathrm{Cr}_{2} \mathrm{O}_{3}$ が遊離する。還元生成物は $\mathrm{FeCr}_{2} \mathrm{O}_{4}$ 成 分の還元段階の初めから主として $(\mathrm{Cr}, \mathrm{Fe})_{7} \mathrm{C}_{3}$ であり， また $\mathrm{MgCr}_{2} \mathrm{O}_{4}$ 成分の還元段階に打いてもこの炭化物が 生成し, $\mathrm{Cr}_{3} \mathrm{C}_{2}$ は生成しない。

\section{$3.4\left(\mathrm{Fe}_{0.5} \mathrm{Mg}_{0.8}\right)\left(\mathrm{Cr}_{0.8} \mathrm{Al}_{0.2}\right)_{2} \mathrm{O}_{4}$}

この合成クロマイトは本実験で用いた試料のらちで最 も天然のクロマイトに近い組成を有するが， $\mathrm{Fe}_{3} \mathrm{O}_{4}$ 成分 を含まないことが相違する，各温度における還元速度曲 線はFig. 8 に示すようであり, $\mathrm{Sp} 3$ と同様に $R_{F C}$ を 境いにして還元速度は急激に低下し $\mathrm{FeCr}_{2} \mathrm{O}_{4}$ 成分が優 先還元されることが容易に推定される， $\mathrm{FeCr}_{2} \mathrm{O}_{4}$ 成分の 還元速度は $1120^{\circ} \mathrm{C}$ では比較的小さいか，温度の上昇と

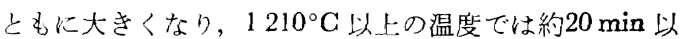
内に還元率が $R_{F C}$ に達する. しかしその後の経過に拉 いて $1150^{\circ} \mathrm{C}$ の場合は長時間還元しても還元率は $R_{F C}$ を 汪とんどこえず，また $1210^{\circ} \mathrm{C} に$ にいてもさほど高くな らない．このように $R_{F C}$ より先の還元反応は $\mathrm{Sp} 3$ よ りかなり高温を必要とし， $1330^{\circ} \mathrm{C} ， 240 \mathrm{~min}$ の還元に よつても完了しない.

種々の条件で還元した試料のX線回折図を Fig. 9 に 示寸. $\mathrm{Cr}_{2} \mathrm{O}_{3}$ は $1120^{\circ} \mathrm{C}$ の還元試料にのみ检出され， $1150^{\circ} \mathrm{C}$ 以上ではまつたく生成しなかつた，金属生成物 は常に $(\mathrm{Cr}, \mathrm{Fe})_{7} \mathrm{C}_{3}$ であつた. クロマイトの回折ピーク は反応の進行とともに $\mathrm{Fe}$ の濃度の低下に対応して高角 度側に移動し，還元率か： $R_{F C}$ に達すると後述の Sp 5 の回折ピークにおよそ一致する．しかしさらに還元率が 高くなつてもその位置はあまり变化せず，別に高角度側 に $\mathrm{MgAl}_{2} \mathrm{O}_{4}$ に近似する回折ピークが現われ，これが次

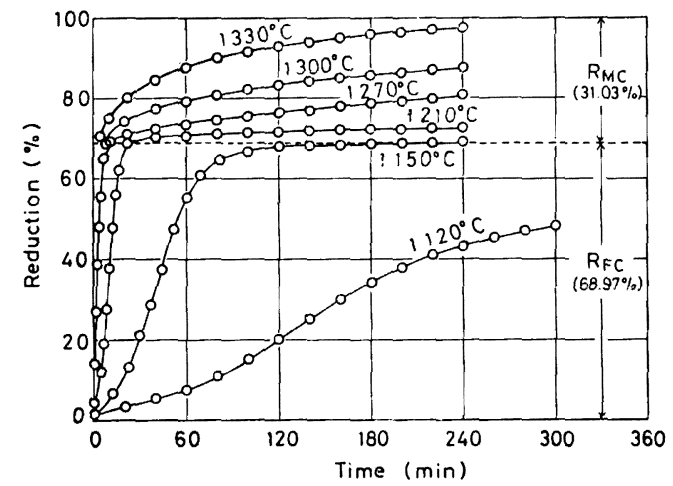

Fig. 8. Reduction curves of $\left(\mathrm{Fe}_{0.5} \mathrm{Mg}_{0.5}\right)$ $\left(\mathrm{Cr}_{\mathbf{0} .8} \mathrm{Al}_{\mathbf{0 . 2}}\right)_{2} \mathrm{O}_{4}$ at various temperatures. 


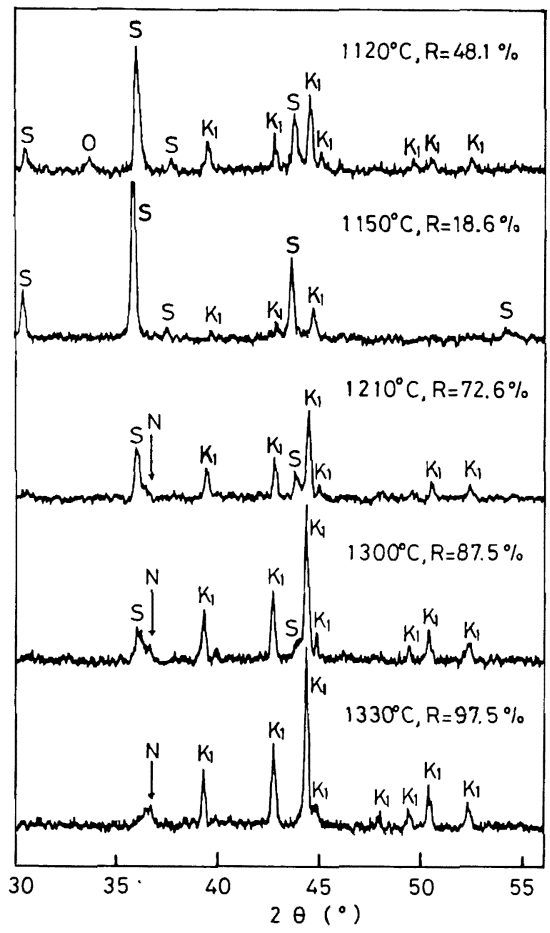

$S$ : chromite(initial composition: $\left.\left(\mathrm{Fe}_{0.5} \mathrm{Mg}_{0.5}\right)\left(\mathrm{Cr}_{0.8} \mathrm{Al}_{0.2}\right)_{2} \mathrm{O}_{4}\right)$ $\mathrm{O}: \mathrm{Cr}_{2} \mathrm{O}_{3}, \mathrm{~N}: \mathrm{MgAl}_{2} \mathrm{O}_{4}, \mathrm{~K}_{1}:(\mathrm{Cr}, \mathrm{Fe})_{7} \mathrm{C}_{3}$

Fig. 9. X-ray diffraction patterns of $\left(\mathrm{Fe}_{\mathbf{0 . 5}} \mathrm{Mg}_{\mathbf{0 . 5}}\right)$ $\left(\mathrm{Cr}_{0.8} \mathrm{Al}_{0.2}\right)_{2} \mathrm{O}_{4}$ reduced at various temperatures.

第に高くなつていく，還元率が $R_{F C}$ をこ学ると $\mathrm{MgO}$ が遊離するはずであるが，高還元率の試料でも明確には 同定できなかつた。これは Sp 3 に比べて $\mathrm{MgO}$ の生成 量が少ないために第 2 順位の回折ピークでは検出できな かつたものと思われる。

\section{$3.5 \mathrm{Mg}\left(\mathrm{Cr}_{0.6} \mathrm{Al}_{0.4}\right)_{2} \mathrm{O}_{4}$}

前述のように $\mathrm{Sp} 4$ は初め $\mathrm{FeCr}_{2} \mathrm{O}_{4}$ 成分が還元し, その後遊離した $\mathrm{Mg}(\mathrm{Cr}, \mathrm{Al}){ }_{2} \mathrm{O}_{4}$ の還元が $1300^{\circ} \mathrm{C}$ 前後 の高温において起こることがわかつた．そこでひき続い てこのスピネル固溶体の還元挙動を調査するために上記 組成の試料を合成し還元実験を行つた。その還元速度は Fig. 10 に示すよらに $1300^{\circ} \mathrm{C}$ 以下では非常に小さく, また $1360^{\circ} \mathrm{C}, 300 \mathrm{~min}$ の高温, 長時間還元によつても 還元反応は完了しない.

還元後の試料のX線回折図を Fig. 11 に示す. 還元率 の上昇にともなつてクロマイトの回折ピークは次第に低 くなるが，その角度はとくに変化せず，別に高角度側 に $\mathrm{MgAl}_{2} \mathrm{O}_{4}$ に近似する回折ピークが現われ，それが次 第に高くなつていく．生成炭化物は Sp 2 の場合と同様 に $\mathrm{Cr}_{3} \mathrm{C}_{2}$ であり，また $1330^{\circ} \mathrm{C}$ 以下の還元試料には前

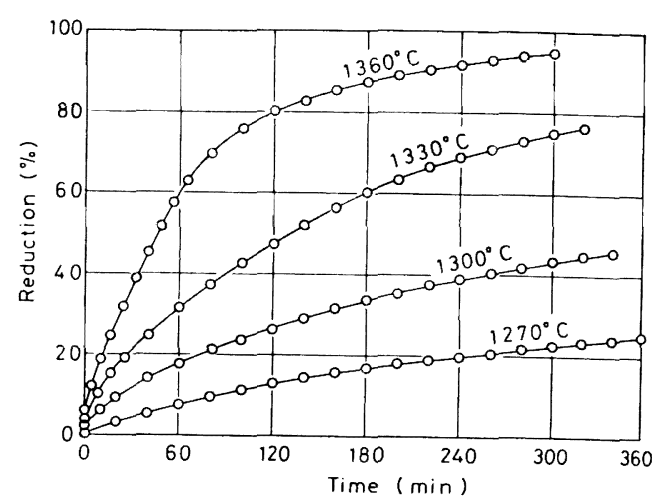

Fig. 10. Reduction curves of $\mathrm{Mg}\left(\mathrm{Cr}_{\mathbf{0 . 6}} \mathrm{Al}_{\mathbf{0 . 4}}\right)_{2} \mathrm{O}_{\mathbf{4}}$ at various temperatures.

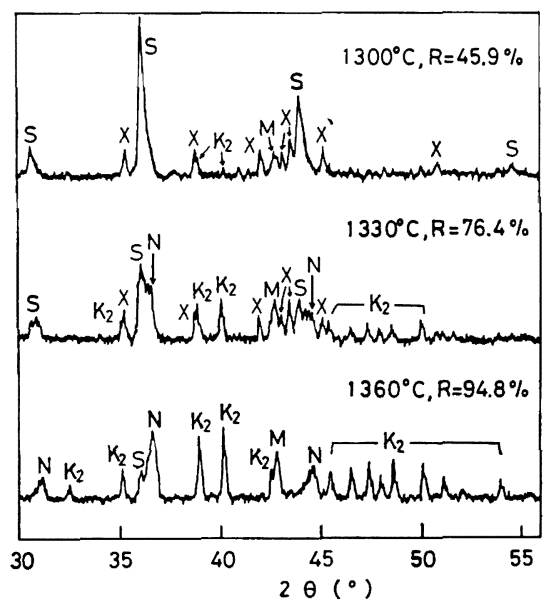

$S$ : chromite (initial composition : $\mathrm{Mg}\left(\mathrm{Cr}_{0.6} \mathrm{Al}_{0.4}\right)_{2} \mathrm{O}_{4}$ ) $N: \mathrm{MgAl}_{2} \mathrm{O}_{4}, M: M G O, K: \mathrm{Cr}_{3} \mathrm{C}_{2}$

Fig. 11. X-ray diffraction patterns of $\mathrm{Mg}\left(\mathrm{Cr}_{\mathbf{0} .6}\right.$ $\left.\mathrm{Al}_{0.4}\right)_{2} \mathrm{O}_{4}$ reduced at various temperatures.

述のX相も検出された。これらの生成物の回折ピークは $\mathrm{MgO}$ の最強の回折ピークと重複しないので，還元率が 低い試料でも $\mathrm{MgO}$ が明確に同定できた.

\section{4. 考察}

\section{$4 \cdot 1$ 還元率の温度変化}

初めに各種クロマイトの還元挙動をお执まかに比較す るために, $120 \mathrm{~min}$ 還元後の到達還元率を温度に対して 図示すると Fig. 12 のようである。

酸化鉄を含むクロマイト（Sp 1, Sp 3, Sp 4)の還元率 は扰よそ $1100 \sim 150^{\circ} \mathrm{C}$ 間で急上昇して $R_{F C}$ に到達 し, いずれも $1150^{\circ} \mathrm{C}$ までの温度で $\mathrm{FeCr}_{2} \mathrm{O}_{4}$ 成分の 還元が完了寸ることを示す。これに対して $\mathrm{MgCr}_{2} \mathrm{O}_{4}$ 成 


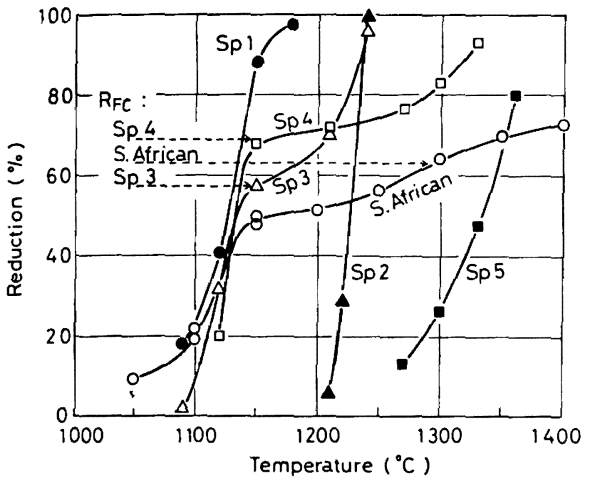

Fig. 12. Variation in degree of reduction with temperature for various chromites (reduction time $=120 \mathrm{~min}$ ).

分の還元温度域はクロマイトにより相違する.すなわち $\mathrm{Sp} 3$ の $\mathrm{MgCr}_{2} \mathrm{O}_{4}$ 成分は Sp 2 と同様に $1200^{\circ} \mathrm{C}$ 付近か ら還元されはじめ約 $1240^{\circ} \mathrm{C}$ で完了するが， Sp 4 の $\mathrm{MgCr}_{2} \mathrm{O}_{4}$ 成分の還元は Sp 5 と同様にさらに高温を必 要とし, $1300^{\circ} \mathrm{C}$ 以下の温度では到達還元率は低い。 のように $\mathrm{FeCr}_{2} \mathrm{O}_{4}$ 成分と $\mathrm{MgCr}_{2} \mathrm{O}_{4}$ 成分の還元温度域 はかなり相違し，また同じ $\mathrm{MgCr}_{2} \mathrm{O}_{4}$ 成分でも $\mathrm{Al}_{2} \mathrm{O}_{3}$ (あるいは $\mathrm{MgAl}_{2} \mathrm{O}_{4}$ ) の含有の有無によつて還元温度域 は相違する. その結果 Sp 3 は 1 150 1 $200^{\circ} \mathrm{C}, \mathrm{Sp} 4$ は $1150 \sim 1270^{\circ} \mathrm{C}$ 間の温度範囲では還元率はほとんど 上昇しない。

Fig. 12 には南阿産クロマイトの還元率変化 2 *も示し てある．還元条件が相違するため政密な比較はできぬ がこれは Sp 4 とおよそ同じ温度域で罡元率が段階的 に変化しており，まず $\mathrm{FeCr}_{2} \mathrm{O}_{4}$ 成分，ついで高温に拉 いて $\mathrm{Mg}(\mathrm{Cr}, \mathrm{Al})_{2} \mathrm{O}_{4}$ 中の $\mathrm{MgCr}_{2} \mathrm{O}_{4}$ 成分が還元される ことがわかる。たたし次の点が相違する。

(1) $1100^{\circ} \mathrm{C}$ 以下の温度に扣ける漫元率が此較的高 W.

(2) 摆元率が $R_{F C}$ に達する温度が高く，また 1350 ${ }^{\circ} \mathrm{C}$ 以上の高温に拈いても還元が完了しない.

(1) は南阿産クロマイトか固溶体成分として $\mathrm{Fe}_{3} \mathrm{O}_{4}$ を 含み, これが $\mathrm{FeCr}_{2} \mathrm{O}_{4}$ 成分の先に還元されるためであ Ђ1)2).

（2）は比較的粗粒の試料（150丸ッシュ以下）を用いた ためと思われ，䠶際に $1300^{\circ} \mathrm{C} ， 120 \mathrm{~min}$ 還元の場合 250 メッュ以下に粉砕した試料は 150 ×ッシュ以下の 試料より約 $5 \%$ 高い還元率を示した。

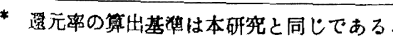

\section{$4.2 \mathrm{Fe}_{2} \mathrm{CrO}_{4}$ 成分の僄元過程}

\section{$4 \cdot 2 \cdot 1$ 熱力学的考察}

Fig. 13 は Fe を含むクロマイトの還元過程を検討す るために作成した反応ガス圧 $\left(P_{\mathrm{CO}}+P_{\mathrm{CO}_{2}}\right) 1$ atm にお ける $\log \left(P_{\mathrm{CO}_{2}} / P_{\mathrm{CO}}\right)$ - $\mathrm{T}$ 図である、各種クロマイトは炭 素還元の途上で実験条件に応じて $P_{\mathrm{CO}_{2}} / P_{\mathrm{CO}}$ 比がこの図 中で高い領域から低、領域一動くと思われる. 本実験の 結果から推定したその領域を図に斜線で示した。起こり 得る反応としては次の（1)〜 (7)を想定しており，困中 の平衡曲線に付された数字は各々下の式の番号に対応す る. 各曲線により区切られた領域内では図示された固相 が安定である.

$$
\begin{aligned}
& \mathrm{C}+\mathrm{CO}_{2}=2 \mathrm{CO} \\
& \mathrm{FeCr}_{2} \mathrm{O}_{4}+\mathrm{CO}=\mathrm{Fe}+\mathrm{Cr}_{2} \mathrm{O}_{3}+\mathrm{CO}_{2} \\
& 3 \mathrm{Cr}_{2} \mathrm{O}_{3}+17 \mathrm{CO}=2 \mathrm{Cr}_{3} \mathrm{C}_{2}+13 \mathrm{CO}_{2} \\
& 7 \mathrm{Cr}_{2} \mathrm{O}_{3}+33 \mathrm{CO}=2 \mathrm{Cr}_{7} \mathrm{C}_{3}+27 \mathrm{CO}_{2}
\end{aligned}
$$

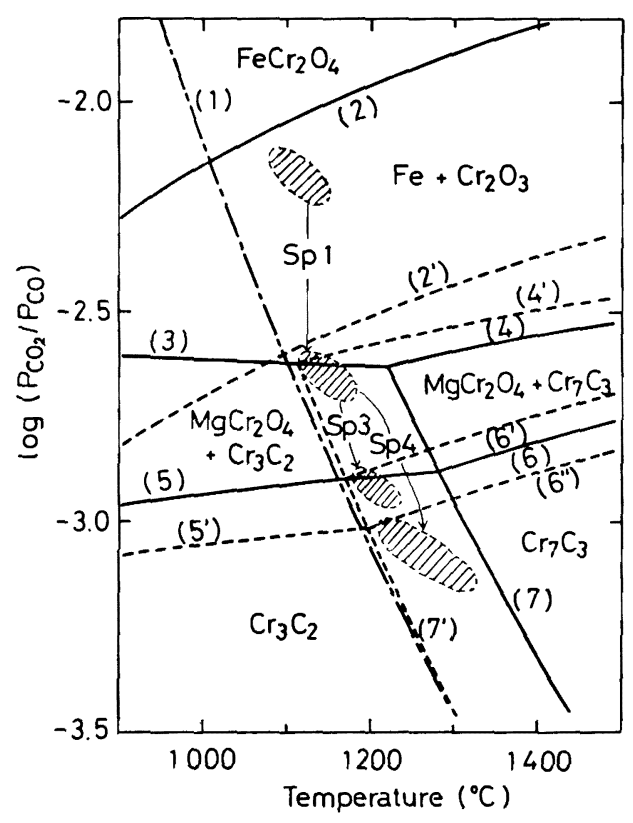

$\left(2^{\prime}\right): a_{\mathrm{HeCr} 204}=0.28,\left(5^{\prime}\right),\left(6^{\prime \prime}\right): a_{\mathrm{MLr}}+\mathrm{O}_{4} \quad 0.31$, $\left(4^{\prime}\right),\left(6^{\prime}\right),\left(6^{\prime \prime}\right),\left(7^{\prime}\right): a_{\mathrm{Cr}_{7} \mathrm{C} 3}=0.15$

Fig. 13. $\mathrm{Log}\left(\mathrm{P}_{\mathrm{CO}_{2}} / P_{\mathrm{CO}}\right)$-temperature diagram for reduction of iron-containing chromites by carbon $\left(P_{\mathrm{CO}}+P_{\mathrm{CO}_{2}}=1\right.$ atm $)$. The numerals attached to the lines correspond to the numbers of equations. 
$\mathrm{FeCr}_{2} \mathrm{O}_{4}$ および $\mathrm{MgCr}_{2} \mathrm{O}_{4}$ の標準生成自由エネルギー

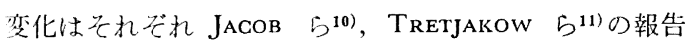
值を用い，他は KUBASCHEWSKI ら ${ }^{12)}$ の集録值を用い た. 複クロマイト中の $\mathrm{FeCr}_{2} \mathrm{O}_{4}$ 打よび $\mathrm{MgCr}_{2} \mathrm{O}_{4}$ 成分 ならびに $\mathrm{Fe}-\mathrm{Cr}-\mathrm{C}$ 系合金中の炭化物の活量 ( a ) は従来 報告されていないが，還元過程の検討を容易にするため 推定した値にもとつ゚く $P_{\mathrm{CO}_{2}} / P_{\mathrm{CO}}$ 比曲線も示した. たた し $\mathrm{Cr}_{3} \mathrm{C}_{2}$ は $\mathrm{Fe}$ の溶解度が低い13)ので常に $a_{\mathrm{Cr}_{3} \mathrm{C}_{2}=1}$ とした.

Sp 1 は初反応 (2)にしたがつて還元され， $r$ 固溶 体を生成し $\mathrm{Cr}_{2} \mathrm{O}_{3}$ を遊離する.この反応の進行中は気 相の $P_{\mathrm{CO}_{2}} / P_{\mathrm{CO}}$ 比は図示されるよらに平衡比に近いか， 終了すると矢印で示されるように低下し $\mathrm{Cr}_{2} \mathrm{O}_{3}$ の還元 が開始する。 $(\mathrm{Fe}, \mathrm{Cr}){ }_{3} \mathrm{C}$ は反応(2)の終りから $\mathrm{Cr}_{2} \mathrm{O}_{3}$ の還元初期にかけて生成するようであり，ついで $(\mathrm{Cr}$, $\mathrm{Fe})_{7} \mathrm{C}_{3}$ が混じり最終的にはこの炭化物のみになる.

$\mathrm{Cr}_{3} \mathrm{C}_{2}$ 相はいかなる場合にも生成しなかつたので， $(\mathrm{Cr}$, $\mathrm{Fe})_{7} \mathrm{C}_{3}$ 中の $a_{\mathrm{Cr}_{7} \mathrm{C}_{3}}$ はかなり小さいと思われる，そこで この值を 0.15 程度に見積ると, 曲線 $(7)$ は ( $\left.77^{\prime}\right)$ に移動 し実験結果とよく対応する。な扰，このさい曲線 $(4)$ は (4') と移動する。

$\mathrm{Sp} 3$ および $\mathrm{Sp} 4$ の $\mathrm{FeCr}_{2} \mathrm{O}_{4}$ 成分の還元では各々 $1150,1120^{\circ} \mathrm{C}$ 以下の温度で少量の $\mathrm{Cr}_{2} \mathrm{O}_{3}$ が遊離する とはい党，大抵の場合 $\mathrm{FeO}$ と $\mathrm{Cr}_{2} \mathrm{O}_{3}$ の両成分が同時 に還元された，そのため生成金属の $\mathrm{Cr}$ 濃度は初めから 高く，かつ浸炭反応も同時に進行するので，Sp 1の上5 に還元初期に $\gamma$ 固溶体や $(\mathrm{Fe}, \mathrm{Cr})_{3} \mathrm{C}$ を生成すること なく，常に $(\mathrm{Cr}, \mathrm{Fe}){ }_{7} \mathrm{C}_{3}$ が生成した. $\mathrm{FeO}$ と $\mathrm{Cr}_{2} \mathrm{O}_{3}$ の 両成分が同時に還元されるのは $a_{\mathrm{F}_{0} \mathrm{Cr}_{2} \mathrm{O}}$ 、が小さいため と考学られる。いまこの值を 0.28 程度に見積ると, 反 応 ( 2 )の平衡 $P_{\mathrm{CO}_{2}} / P_{\mathrm{CO}}$ 比は曲線 $\left(2^{\prime}\right) \quad$ となり曲線 $\left(4^{\prime}\right)$ に接近するので同時還元が説明できる.

$\mathrm{Sp} 3$ 拈よび $\mathrm{Sp} 4$ は $\mathrm{FeCr}_{2} \mathrm{O}_{4}$ 成分の還元が終了する と，それぞれ $\mathrm{MgCr}_{2} \mathrm{O}_{4}, \mathrm{Mg}(\mathrm{Cr}, \mathrm{Al})_{2} \mathrm{O}_{4}$ が残る。これ らの成分の還元は $1200^{\circ} \mathrm{C}$ 前後から起るか， そのため には気相の $P_{\mathrm{CO}_{2}} / P_{\mathrm{CO}}$ 比は Fig. 13 に拈いて各々矢印 で示されるよらに低下せねばならない。なお $\mathrm{Sp} 4$ の場 合は $\mathrm{Mg}(\mathrm{Cr}, \mathrm{Al})_{2} \mathrm{O}_{4}$ 中の $a_{\mathrm{MgCr}_{2} \mathrm{O}_{4}}$ を 0.30 程度と仮 定して平衡 $P_{\mathrm{CO}_{2}} / P_{\mathrm{CO}}$ 比を求めると曲線( $\left.6^{\prime \prime}\right)$ となりほ ぼ实験結果と対応する，これらの成分の還元段階に拈い て屯還元生成物は矢張りいずれる $(\mathrm{Cr}, \mathrm{Fe})_{7} \mathrm{C}_{3}$ であり, $\mathrm{Cr}_{3} \mathrm{C}_{2}$ より $(\mathrm{Cr}, \mathrm{Fe})_{7} \mathrm{C}_{3}$ の方が $\mathrm{Cr}$ 活量の小さいことが らかがわれる.

以上の上うに本実験結果は平衡論的考察でかなりの程 度説明できたが，このことは，逆にいえぱ，本研究の結
果が平衡論的条件の変更により変り得ることを子预させ る.すなわちたとえば全圧 $\left(P_{\mathrm{CO}}+P_{\mathrm{CO}_{2}}\right)$ を低下させれ ば，図中の曲線（1）はより低温側にずれ，反応温度も低 温側にずれることが子想され，実際に著者ら㣙より確 かめられているが，このような全圧の効果は別に検討す る.

\section{2 .2 速度論的要因の検討}

Fig. 14 は Sp 1, Sp 3 扰よび Sp 4 の $\mathrm{FeCr}_{2} \mathrm{O}_{4}$ 成分 の還元速度を比較するために，1120 および $1150^{\circ} \mathrm{C} に$ ついて $R / R_{F C}$ を求めて図示したものである. 両温度と も初期の還元速度は Sp 1, Sp 3, Sp 4 の順であり, 組 成の複雑なクロマイトほど小さいしかし $R / R_{F C}$ が 0.25 をこえると Sp 1 の還元速度は急に小さくなり 3 試料中最小となる.この原因としては Sp 1 が比較的粗 粒であることと $\mathrm{FeO}$ 成分が優先還元することがあげら れ，とくに後者が重要であると思われる．FeO成分が優 先還元した段階では $\mathrm{Fe}$ を主成分とする金属相と $\mathrm{Cr}_{2} \mathrm{O}_{3}$ 相が混在している。ところが同様の条件に抢ける $\mathrm{Cr}_{2} \mathrm{O}_{3}$ 単独 (-325 ィッシュ) の炭素還元速度 ${ }^{15) *}$ は Fig. 14 に点線で併示したように $1140^{\circ} \mathrm{C}$ 付近では著しく小さ い.したがつて Sp 1 の還元に括いて $\mathrm{Cr}_{2} \mathrm{O}_{3}$ 相を分離 してしまえば分離 $\mathrm{Cr}_{2} \mathrm{O}_{3}$ 相の粒径が大きいほど共存 $\mathrm{Fe}$ 相への生成 $\mathrm{Cr}$ 相の溶解による加速効果が小さくなり, その後の還元は $\mathrm{Cr}_{2} \mathrm{O}_{3}$ 相単独の還元条件と類似してく る.これに対して $\mathrm{Sp} 3$ 打よび $\mathrm{Sp} 4$ は $a_{\mathrm{FeCr}_{2} \mathrm{O}}$ が小 さいので $\mathrm{FeO}$ と $\mathrm{Cr}_{2} \mathrm{O}_{3}$ がほぼ同時に還元して直ちに $(\mathrm{Cr}, \mathrm{Fe})_{7} \mathrm{C}_{3}$ を生成するので, 上記の溶解過程は律速段階 とはならずに比較的速やかに還元されるものと考光られ る.

$\mathrm{Sp} 3$ と $\mathrm{Sp} 4$ の $\mathrm{FeCr}_{2} \mathrm{O}_{4}$ 成分の還元速度の差は

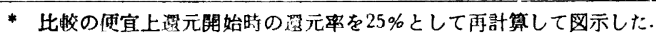

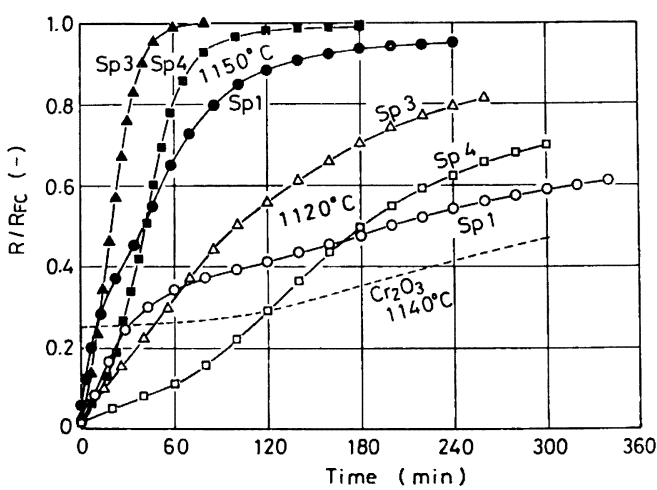

Fig. 14. Plots of $R / R_{F C}$ vs. reduction time for iron-bearing chromites. 
$\mathrm{Al}_{2} \mathrm{O}_{3}$ 成分の固溶の有無による $a_{\mathrm{FeC}_{2} \mathrm{O}_{4}}$ の㦈によるも のと考えられる。

\section{$4.3 \mathrm{MgCr}_{2} \mathrm{O}_{6}$ 成分の䏅元過程}

\section{3 .1 熱力学的考察}

$\mathrm{Fe}$ を含むクロマイトの $\mathrm{MgCr}_{2} \mathrm{O}_{4}$ 成分の炭素還元に 関する熱力学的検討はすでに前節において行つた。本項 では Sp 2 および Sp 5 についてのみ検討することと 乙, 同様の方法により $\log \left(P_{\mathrm{CO}_{2}} / P_{\mathrm{CO}}\right)$ 対 T図を作成し Fig. 15 に示した. 生成炭化物の活量はいずれも 1 とし Sp 5 は $a_{\mathrm{MgCr}_{2} \mathrm{O}_{4}}=0.3$ と見皘つた。 また同図には参考 のため $\mathrm{Cr}_{2} \mathrm{O}_{3}$ の還元反応の平衡曲線も示した.

最終の生成炭化物は常に $\mathrm{Cr}_{3} \mathrm{C}_{2}$ であつたので, $\mathrm{Sp} 2$, Sp 5 それぞれの炭素還元に扣ける存在領域は図中の斜 線部のよらに推測される。還元開始温度は平衡諭的還元 開始温度よりかなり高温であり，また Sp 3 および Sp 4 のそれよりも高温であり Fe の含有の有無による差が認 められる。

X相は低温および反応初期において生成したので，父 相の $P_{\mathrm{CO}_{2}} / P_{\mathrm{CO}}$ 比が高く平衡分王比に近い場合に生成す ると推定される。このX相の $\mathrm{X}$ 線回折デー夕は

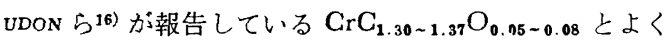
一致するので，この種のオキシカーハイト相と推定され $3^{17)}$.

\section{$4 \cdot 3 \cdot 2$ 速度論的要因の検討}

$\mathrm{Fe}$ を含む複クロマイト中の $\mathrm{MgCr}_{2} \mathrm{O}_{4}$ および $\mathrm{Mg}$ $(\mathrm{Cr}, \mathrm{Al})_{2} \mathrm{O}_{4}$ 成分の還元はそれぞれ $\mathrm{Sp} 2$ 扰よび Sp 5 より概して速く， Fe の反応促進作用が認められた.

$\mathrm{MgCr}_{2} \mathrm{O}_{4}$ と $\mathrm{Mg}(\mathrm{Cr}, \mathrm{Al}){ }_{2} \mathrm{O}_{4}$ を比較すると前述のよ

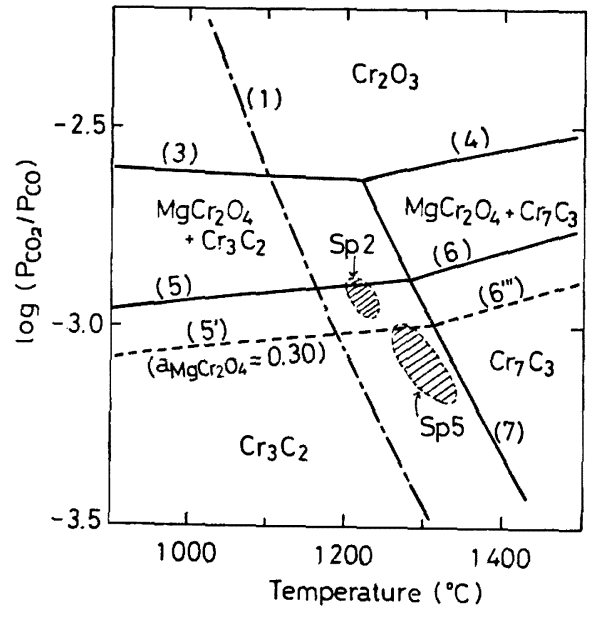

$\left(6^{\prime \prime \prime}\right): a_{\mathrm{MgCr}_{20}}=0.30, a_{\mathrm{Cr}_{7 \mathrm{C} 3}}=1.0$

Fig. 15. $\log \left(P_{\mathrm{CO}_{2}} / P_{\mathrm{CO}}\right)$-temperature diagram for reduction of picrochromites by carbon $\left(P_{\mathrm{CO}}+P_{\mathrm{CO}_{2}}=1\right.$ atm $)$.
らに後者の方が非常に難還元性である. この原因として はすでに検討したよらにまず $a_{\mathrm{MgCr}_{2} \mathrm{O}_{4}}$ の差があげられ る.さらに速度論的要因としては $\mathrm{MgAl}_{2} \mathrm{O}_{4}$ に近い組成 の比較的緻密なスピネル層が $\mathrm{Mg}(\mathrm{Cr}, \mathrm{Al})_{2} \mathrm{O}_{4}$ の周囲に 形成され，これが反応物質の抬散を妨げることが考壳ら れる.Fig.9 および11のX線回折図にみるよらに Mg $(\mathrm{Cr}, \mathrm{Al})_{2} \mathrm{O}_{4}$ の回折ピークは還元の進行にともなつて連 続的に高角度側に移動せず，別に $\mathrm{MgAl}_{2} \mathrm{O}_{4}$ に近似する 回折ピークが現われ，これが次第に高くなつていく。こ のことから $\mathrm{Mg}(\mathrm{Cr}, \mathrm{Al})_{2} \mathrm{O}_{4}$ は細粒であつてすトポヶ カルに還元され，その周囲にスピネル層が形成されると 推定される.

クロム鉣石中のクロマイトは例外なく $\mathrm{Al}_{2} \mathrm{O}_{3}$ をかな り高濃度に含むので，還元後期には $\mathrm{MgAl}_{2} \mathrm{O}_{4}$ 相が生成 (1)2)6) 18) 19), これが残存するクロマイト粒を包むことも 観察されている20121). 前述の南阿産クロマイトの還元に おいて，とくに高温域の還元率が Sp 4 に比し著しく低 いのは比較的粗粒であるためスピネル凰の反応阻害作用 がいつそら強く現われたことによると考えられる。

予備還元法によるフェロクロムの製鍊 ${ }^{22)}$ 23)に执いては 還元率の上昇にともない，その後の電気炉製錬の電力原 単位はほぼ直線的に低下するとされている. 現在実操業 に扣いては $60 \%$ 前後の睘元率が得られているが，これ をさらに高めようとすると上記のスピネル層の形成が問 題となる．鉱石粉砕の強化など当面の対策とともに，今 後は還元後期の反応機構をより詳細に解明し，その知見 にもとつうき根本的な解決策を見出す必要があるう.

\section{5. 結言}

天然のクロマイトの炭素還元過程を明らかにするため の基礎的知識を得ることを目的として，合成した 2 種の 単純クロマイト $\left(\mathrm{FeCr}_{2} \mathrm{O}_{4}, \mathrm{MgCr}_{2} \mathrm{O}_{4}\right)$ と 3 種の複クロ マイト $\left(\left(\mathrm{Fe}_{0.5} \mathrm{Mg}_{0.5}\right) \mathrm{Cr}_{2} \mathrm{O}_{4}, \quad\left(\mathrm{Fe}_{0.5} \mathrm{Mg}_{0.5}\right) \quad\left(\mathrm{Cr}_{0.8} \mathrm{Al}_{0.2}\right)_{2}\right.$ $\left.\mathrm{O}_{4}, \mathrm{Mg}\left(\mathrm{Cr}_{0.6} \mathrm{Al}_{0.4}\right)_{2} \mathrm{O}_{4}\right)$ の $\mathrm{CO}$ 雾国気中における炭素 罯元奏験を行い，熱力学的ならびに速度論的検討を加え た. 得られた結果を要約すると扰よそ次のよらである.

(1) $\mathrm{FeCr}_{2} \mathrm{O}_{4}$ の還元は $1090^{\circ} \mathrm{C}$ 付近から起こり約 $1150^{\circ} \mathrm{C}$ 末で温度で完了する. その過程においてまず $\mathrm{FeO}$ 成分の還元が先行し, その後遊離した $\mathrm{Cr}_{2} \mathrm{O}_{3}$ の還 元が起る. その結果金属相は還元初期に扣いては $\gamma$ 固溶 体であり，ついでこれと $(\mathrm{Fe}, \mathrm{Cr})_{3} \mathrm{C}$ 扰よび $(\mathrm{Cr}, \mathrm{Fe})_{7} \mathrm{G}_{3}$ の共存状態をへて，最終的には $(\mathrm{Cr}, \mathrm{Fe})_{7} \mathrm{C}_{3}$ になる.

(2) $\mathrm{MgCr}_{2} \mathrm{O}_{4}$ の還元は約 $1200^{\circ} \mathrm{C}$ から開始し, $1240^{\circ} \mathrm{C}$ においてほぽ完了する。これに対して $\mathrm{Mg}$ $\left(\mathrm{Cr}_{0.6} \mathrm{AI}_{0.4}\right)_{2} \mathrm{O}_{4}$ の還元はさらに高温を要し， $1300^{\circ} \mathrm{C}$ 以 
下では到達還元率は低い. 生成炭化物は両者とも $\mathrm{Cr}_{3} \mathrm{C}_{2}$ でありそそのほか還元率が低い試料にはクロムのオキシ カーパイドと推定される物質も検出された.

(3) $\left(\mathrm{Fe}_{0.5} \mathrm{Mg}_{0.5}\right) \mathrm{Cr}_{2} \mathrm{O}_{4}$ お。よひ $\left(\mathrm{Fe}_{0.5} \mathrm{Mg}_{0.5}\right)\left(\mathrm{Cr}_{0.8}\right.$ $\left.\mathrm{Al}_{0.2}\right)_{2} \mathrm{O}_{4}$ は初め $\mathrm{FeCr}_{2} \mathrm{O}_{4}$ 成分, ついで $\mathrm{MgCr}_{2} \mathrm{O}_{4}$ 成 分の 2 段階に還元される. $\mathrm{FeCr}_{2} \mathrm{O}_{4}$ 成分は単純クロマ イトの $\mathrm{FeCr}_{2} \mathrm{O}_{4}$ とおよそ同じ温度範囲で還元されるが $\mathrm{FeO}$ と $\mathrm{Cr}_{2} \mathrm{O}_{3}$ の両成分が注济同時還元され，かつ初 めから $(\mathrm{Cr}, \mathrm{Fe})_{7} \mathrm{C}_{3}$ が生成することが相違する。このこ とについて熱力学的に検討し, $\mathrm{FeCr}_{2} \mathrm{O}_{4}$ 成分の活量が小 さいためにその平衡 $P_{\mathrm{CO}_{2}} / P_{\mathrm{CO}}$ 比が $\mathrm{Cr}_{2} \mathrm{O}_{3}$ のそれに近 ずくためと推定した． $\mathrm{MgCr}_{2} \mathrm{O}_{4}$ 成分の還元段階におい てもやはり $(\mathrm{Cr}, \mathrm{Fe})_{7} \mathrm{C}_{3}$ が生成する。これはすでに生成 している比較的 $\mathrm{Cr}$ 濃度の低い $(\mathrm{Cr}, \mathrm{Fe})_{7} \mathrm{C}_{3}$ 中に新たに 生成する $\mathrm{Cr}$ が固溶するためであり, その結果還元速度 はそれぞれ $\mathrm{MgCr}_{2} \mathrm{O}_{4}$ および $\mathrm{Mg}\left(\mathrm{Cr}_{0.6} \mathrm{Al}_{0.4}\right)_{2} \mathrm{O}_{4}$ より いく分大きくなる.

(4) $\mathrm{Al}_{2} \mathrm{O}_{3}$ を含むクロマイトは $\mathrm{MgCr}_{2} \mathrm{O}_{4}$ 成分の還 元速度が著しく小さく, Fe を含を場合でも還元完了に は $1300^{\circ} \mathrm{C}$ 以上の高温を要する。この原因は $\mathrm{MgCr}_{2} \mathrm{O}_{4}$ 成分の活量が小さいことに加えて, クロマイトの周囲に $\mathrm{MgAl}_{2} \mathrm{O}_{4}$ 層が形成され反応物質の拡散を阻害するため と推定した.

（5）以上の結果にもとづきクロム鉱石中のクロマイ トの炭素還元過程について検討するとともに, 予備還元 法における到達還元率を現在のレベルよりさらに高める ためには $\mathrm{Al}_{2} \mathrm{O}_{3}$ を含んた $\mathrm{MgCr}_{2} \mathrm{O}_{4}$ 成分の還元機構の 解明が重要であることを指摘した。

㧍わりに本研究の遂行にあたり有益な御助言をいただ いた東北大学選鉱製錬研究所長大谷正康教授ならびに実 験に協力された室蘭工大加藤久一技官に謝意を表する.

\section{交献}

1) 片山 博. 田中章彦：鉄と铜，60（1974）9, p. 1289

2) 片山 博：鉄と銅，63（1977）2，p. 207
3 ) 片山 博: 日本金属学会誌, 40 (1976) 10, p. 993

4 ）片山 博：日本金属学会誌，41 (1977) 3, p. 275

5 ) 片山 博：日本金属学会誌，41（1977）5, p. 427

6 ) A. $N$. Morozov, S. S. Lisnyak, and A. $M$. Belikov: Stal in Eng., (1963) 2, p. 119

7 ) 成田貴一: 鉄と鋼, 52 (1966) 7, p. 1098

8 ）佐々木茂二：窑業協会誌, 66 (1958) 4, G 113

9 ) W. C. Allen: Am. Mineralogist, 5 (1966), p. 239

10) $K . T$. Jасов and $C$. B. Alcock: Met. Trans., 6 B (1975), p. 215

$11) J . D$. Tretjakow und $H$. Schmalzried: Ber. Bunsenges. physik. Chem., 69 (1965) 5, p. 396

12) $O$. Kubaschewski, $E . L l$. Evans, and $C . B$. Alcock: Metallurgical Thermochemistry, (1967), p. 421 [Pergamon Press],

13) $N . R$. Griffing, $W . D$. Forgeng, and $G \cdot W$. Healy: Trans. Met. Soc. AIME, 224 (1962) 2, p. 148

14) 片山博, 德田昌則: 日本金属学会講演概要, 1977, 10, p. 187

15) 片山 博：鉄と罁，62 (1976) 11，S S 16

16) D. Thibaudon, $M$. Roubin, $R$. A. Paris, and $J$. PARIs: Planseeber. Pulvermet., 20 (1972) 2, p. 129

17) 片山博, 徳田昌則：日本金属学会講演概要, 1978，4，p. 165

18）高香利夫, 飯皂 繁: 鉱物学雑誌, 8 (1967) 4, p. 251

19）山岸一雄, 佐賀淳一：フェロアロイ, 18 (1969) 5, p. 196

20) V. Ya. Belogurov, L. M. Izrailev, $V$. $S$. Kudryavtsev, $V . V$. Ponomarenko, and $S . A$. Pchelkin: Steel in USSR, (1972), p. 511

21) V. S. Kudryavtsev, L. P. Kostenenko, L. F. Shchugareva, $V$. Ya. Belogurov, and $L$. $L$. Zav'Yalova: Russian Metal, (1975), 6, p. 5

22）市川和男, 小沢展哉, 牛山和久, 山中 稔: 日新 製鋼技報，26(1972)，p. 78

23）米花昭二, 杉田喜四郎, 木村義行, 古井健夫, 福 田充美：鉄と鋼，61（1975）4，S 40 